\title{
HEGEMONIC FEDERALISM: THE DEMOCRATIC IMPLICATIONS OF THE UN SECURITY COUNCIL'S "LEGISLATIVE" PHASE
}

\author{
Craig Forcese*
}

\begin{abstract}
Several recent UN Security Council anti-terrorism resolutions amount to legislation for the international community. The Security Council's new approach raises real predicaments for those states that, in their domestic system of government, are democracies. Not least, the Council risks disturbing the carefully balanced features of liberal democracy, including the very separation of powers on which functioning democracies are built. The article that follows explores this contention, with a particular focus on the implications of Security Council action for Canadian democracy. It concludes that the Security Council's legislative phase creates a new species of international/domestic legal interface, perhaps best described as "hegemonic federalism" - that is, a system in which the Security Council asserts plenary law-project authority over the Canadian federal executive, which in turn responds with direct implementation of the international resolution or strongly encourages (and in majority Parliaments likely ensures) compliance by Parliament.
\end{abstract}

\section{INTRODUCTION}

Never have so many people been governed by leaders they have themselves elected. In the late 1980 s, just prior to the end of the Cold War, a mere $40 \%$ of the world's states were electoral democracies. By 2005, this figure had reached $64 \%{ }^{1}$

* Associate Professor, Faculty of Law, University of Ottawa, Canada. BA (McGill), MA (Carleton), LLB (Ottawa), LLM (Yale); of the bars of New York, the District of Columbia and Ontario, cforcese@ottawa.ca. Sincere thanks go to the Social Science and Humanities Research Council of Canada for its support for this project. The author would also like to thank Koren Marriott, $3^{\text {rd }}$ year LLB candidate at the University of Ottawa, for her comments on drafts of this article, and to the many organisers from the ANZSIL, CCIL, ASIL and JSIL who made possible the "Fostering a Scholarly Network" initiative for which this article was prepared. In this last regard, particular thanks go to Campbell McLachlan and to Jack Wass and the team at the VUWLR.

1 Freedom House Freedom in the World 2006 www.freedomhouse.org (accessed 1 January 2007). 
This is not to say that democracy is perfected in these states, or that democracy itself is perfect. Democracy may, however, be less imperfect than its alternatives. ${ }^{2}$ No other system of government but a democracy ensures that the excesses of a few are held in check by the leveling wisdom of the many.

It is, however, one thing to agree that democracy is the rule of the majority: it is quite another to design a workable democratic system. "Liberal" democracies - the most commonplace species of modern democracy - are built on two foundational principles. First, government should be by the citizenry, at least indirectly. In practice, this "government by the people" is conducted via universal suffrage; that is, the election of representatives by the entire electorate.

Second, government by the citizenry cannot become a tyranny of the majority. A liberal democracy is, in other words, one preserving rights and liberties and adhering to a rule of law. Many, if not most, liberal democracies meet this objective by partitioning power between different branches of government, ensuring that absolute power can be usurped by no one actor or institution. Thus, powers are separated to varying degrees in the constitutional fabrics of modern liberal democracies, creating a system of checks and balances and accountability of branches, one to the other.

Democracy, however, stops at international borders. Even though now mostly comprised of at least approximately democratic states, the international system is not democratic. The cornerstone of international law is sovereign equality of states, not democratic accountability. Sovereign equality has a pseudo-democratic aspect in the sense that it allows choice. For instance, rulemaking in the international system is often described as a matter of state consent, expressed most notably through treaty making. Dissent is also possible in relation to the formation of new customary principles, albeit in the narrow circumstances allowed by the persistent objector rule. However, the capacity to resist international rule-making is not the same as democratic rule-making. Democracy accepts that, subject to certain limits, a majority can decide for everyone. Sovereign equality is the precise antithesis of this rule.

The international system includes institutions that, at first blush, bear some resemblance to those found in democratic states. The United Nations system, in particular, includes a General Assembly, a Security Council and an International Court of Justice (ICJ). These bodies have an appearance evocative of domestic legislative, executive and judicial branches. Nevertheless, functionally the United Nations (UN) Charter creates relationships between UN organs not even loosely analogous to those existing between domestic branches of government. In fact, a simply textualist reading of

2 See, for example, Winston Churchill's famous comments to this effect. Robert Rhodes James (ed) Winston S Churchill: His Complete Speeches, 1897-1963 (Chelsea House Publishers, New York, 1974) 7566, citing a speech made in the House of Commons on 11 November 1947. 
the UN Charter obscures tendencies creating even greater differences between domestic and international systems.

Specifically, probing the actual workings of bodies such as the Security Council, international jurists have described the existence of "hegemonic international law"; that is, a pattern of norm creation that gives primacy to the most powerful state (or states) in the international system. When hegemony is exercised through the devices of the international system's most powerful organ - the Security Council - a minority makes rules for everyone.

This pattern is not new. By design, the Security Council is an institution operating without regard to sovereign equality and disproportionately controlled by the most powerful states. Recently, however, the Council has exercised its muscles in a qualitatively different way. Rather than the limited dictates traditionally issued under the Council's potent Chapter VII powers, several recent anti-terrorism resolutions amount to legislation for the international community. Rolled together in a single institution with an exclusive state membership, this pattern replaces sovereign equality, not with democracy, but with oligarchy; that is, governance by a few.

There is nothing necessarily pejorative in using oligarchy to describe an international system otherwise often characterised as anarchic. True, some states complain that the Council's legislative behaviour does violence to state sovereignty. Crimping state sovereignty, however, is exactly what a functioning Security Council must occasionally do. But the sovereignty complaint suggests more subtle problems with hegemonic international law as exercised through an autocratic Council. Namely, the Security Council's new approach raises real predicaments for those states that, in their domestic system of government, are democracies. Not least, the Council risks disturbing the carefully balanced features of liberal democracy, including the very separation of powers on which functioning democracies are built.

This article explores these contentions, with a particular focus on the implications of Security Council action for Canadian democracy. It does so in three parts. Part I probes the concept of democracy invoked in this introduction, describing the components of classic liberal democracy. It highlights several generic challenges to democratic governance presented by multilateralisation of decision-making. Part II then focuses specifically on the UN Security Council, tracing its structure and functions and examining its relationship with both the General Assembly and the ICJ. Part III explores the implications of post-9/11 Council activity for democratic deliberation in Canada.

The article concludes that the Security Council's legislative phase creates a new type of international-domestic legal interface, perhaps best described as "hegemonic federalism"; that is, a system in which the Security Council asserts plenary law-project authority over the federal executive, which in turn responds with direct implementation of the international resolution or strongly encourages (and in majority parliaments likely ensures) compliance by parliament. 


\section{THE DEMOCRATIC ACCOUNTABILITY BENCHMARK}

\section{A Classic Model of Democratic Accountability}

Democracy is "that form of government in which the sovereign power resides in the people as a whole, and is exercised either directly by them ... or by officers elected by them." ${ }^{13}$ In a modern representative democracy, the expectation is that the elected representatives of the people will exercise the authority of the state. ${ }^{4}$ In a modern democracy, however, not all - or even most - of the people governing in contemporary democracies are elected. The modern, administrative state depends on a massive bureaucratic apparatus, staffed mostly by unelected officials. The classic response in the liberal democratic tradition is to shape rules ensuring that those who are not selected by the people are somehow accountable to those who are. Elected officials, in other words, have primacy over their unelected counterparts. Together, these rules create the two levels of democratic accountability - direct election and the pre-eminence of the elected over the appointed - and ensure that majorities shape governance, however indirectly.

Of course, majority rule does not always generate the right policies, and sometimes the majority will make serious errors. A democracy must therefore have some cure for - and safeguards against the mistakes of the majority. In a liberal democracy, the answer comes in the form of a shared code specifying that the democratic will of the majority stops where the rights of the individual and the minority begin. A liberal democracy agrees, therefore, to a policy of at least partial abstinence in relation to violations of civil and political rights. More grudgingly (and more rarely), it intervenes to protect certain economic and social rights, even when inconsistent with the dictates of the majority.

Liberal democracy is, therefore, a system that accepts only provisionally the wisdom of the majority and protects against its natural fallibility by carving out spaces where even the democratic state may not go.

Checking the excesses of the majoritarian impulse in order to preserve rights requires a separate, third set of accountability mechanisms less receptive to democratic desires. Elected officials, and the unelected bureaucracy they direct, are creatures and servants of the majority. They are ill-equipped to prevail in the face of that majority's opposition. Thus, if there are to be rights that the democratically-elected government cannot trump, those rights must be protected by institutions

3 J A Simpson and Edmund Weiner (eds) Oxford English Dictionary (vol IV, Oxford University Press, Oxford, 1989) 442-3.

4 This part amplifies a discussion found in Craig Forcese and Aaron Freeman Laws of Government: The Legal Foundations of Canadian Democracy (Irwin Law, Toronto, 2005) and also appearing in the discussion paper drafted by Craig Forcese for the Law Commission of Canada Crossing Borders: Law in a Globalized World (Government of Canada, Ottawa, 2006). 
other than those controlled by the majority itself. In practice, these bodies are courts protected by a concept resistant to raw democratic accountability: judicial independence.

In at least the Anglo-Canadian and American liberal democratic tradition, the net result of these systems of accountability are three branches of government - the legislature, mostly or entirely elected; the executive, governed by directly elected chiefs (in republican systems) or somehow subordinated to the elected legislature (in parliamentary systems); and the judiciary, at least partially protected from the manoeuvrings of the other two "political" branches.

In much modern western political thought, the "separation of powers" between these three branches is seen as essentially synonymous with liberty. ${ }^{5}$

\section{B Democratic Accountability and Globalisation}

Modern governments do not, however, operate in splendid isolation. Policy-making influence and power is increasingly "multilateralised" in international venues, raising new questions of accountability. Globalised governance exercised through international institutions raises two key democratic accountability preoccupations.

First, the very manner in which intergovernmental organisations function raises concerns about democratic accountability. Specifically, these institutions often conduct their activities insulated from meaningful scrutiny by a broader public. ${ }^{6}$ Except in the rarest of circumstances - such as the negotiations of the treaties governing the International Criminal Court or the ban on landmines international treaty-making is an obscure process. Negotiations are in camera, and treaties are concluded by the negotiating states without any public hearing or vetting process.

Second, in international policy-making the executive branches of state governments are enhanced at the expense of the other branches. Legislative bodies exercise little control over international policy-making. As Eric Stein has observed: "A new level of normative activity superimposed on national democratic systems makes citizen participation more remote, and parliamentary control over the executive, notoriously loose in foreign affairs matters, becomes even less effective."7 Meanwhile, courts often extend substantial deference to the foreign affairs prerogatives of the executive branch. ${ }^{8}$

5 See, for example, Charles de Secondat, Baron de Montesquieu Spirit of Laws, book 11, ch 6 (1748), available at www.constitution.org (accessed 25 January 2007).

6 See discussion in Eric Stein "International Integration and Democracy: No Love at First Sight" (2001) 95 Am J Int'l L 489, 490

7 Ibid, 490

8 This tradition is particularly acute in the United States. See Baker v Carr (1962) 369 US 186, 210-11 Brennan J for the Court. 
The impact of this short-circuiting of the democratic process is most apparent where international obligations, once entered into by the executive, compel states to embark on policies that would otherwise be carefully scrutinised by Parliaments, courts or citizens. The World Trade Organisation and other free trade agreements, for instance, are frequently criticised for constraining the "sovereignty" of their members - the freedom to choose a given policy path. ${ }^{9}$

As a practical matter, Canadian law guards poorly against what Stein calls the "deparliamentisation" of the international political processes, a point illustrated by the rules on the incorporation of international treaties into Canadian law. As a matter of international law, international treaties bind a state once it has signified consent to be bound. ${ }^{10}$ How this consent is indicated varies, but usually takes the form of a simple signature by an accredited representative or, more frequently with multilateral treaties, signature followed by ratification. ${ }^{11}$ International law does not dictate the procedure to be followed in completing this ratification. Instead, each state's domestic law governs this process.

In Canada, signifying consent to be bound is the prerogative of the executive branch, operating pursuant to "royal prerogative." As a result, the executive may choose to sign and ratify an international treaty, binding Canada as a matter of international law, without any recourse to Parliament. ${ }^{12}$

In sum, the content of international obligations may not be the product of (democratic) deliberations between branches of government - instead marking an executive dominance - and may lock states into policy directions not easily alterable. The question to which this article now turns is whether UN Security Council activity in the post-9/11 era has exacerbated these concerns.

\section{THE UN SECURITY COUNCIL AND "HEGEMONIC INTERNATIONAL $L A W^{\prime \prime}$}

While the concept of democratic accountability is the touchstone of liberal democratic states, the notion of "sovereign equality" of states animates public international law. ${ }^{13}$

9 See, for example, the complaints of one Canadian parliamentarian: Paddy Tornsey "The World Trade Organization and Parliamentarians" (2003) 26:3 Canadian Parliamentary Review 12, 12 www.parl.gc.ca (accessed 10 December 2006).

10 See Vienna Convention on the Law of Treaties (23 May 1969) 1155 UNTS 331; 8 ILM 679, arts 2 and 26.

11 Ibid, art 11

12 Hugh Kindred and others International Law Chiefly as Practiced in Canada (6 ed, Emond Montgomery, Toronto, 2000) 103. For an excellent overview of treaty ratification processes in Commonwealth countries, see Joanna Harrington "Redressing the Democratic Deficit in Treaty Law Making: (Re-)Establishing a Role for Parliament" (2005) 50 McGill LJ 465.

13 See, for example, General Assembly Resolution 2625 (Friendly Relations Resolution) (XXV) (24 October 1970) A/5217, 121 
In the United Nations system, sovereign equality explains the decision-making process in the UN General Assembly: one state, one vote. ${ }^{14}$ Applied in this procedural fashion, sovereign equality produces obvious incongruities: the largest states are technically no more influential than the smallest. The most powerful states have no more formal decision-making influence than the most weakest. The most democratic state has no primacy over the most despotic.

One state, one vote does not run through the UN system, however. Indeed, sovereign equality may be a poor approximation of how international law operates. Others have instead perceived a structure of "hegemonic international law" (HIL), ${ }^{15}$ described as a system that "jettisons or severely undervalues the formal and de facto equality of states, replacing pacts between equals grounded in reciprocity with patron-client relationships in which clients pledge loyalty to the hegemon in exchange for security or economic sustenance."16 As Detlev Vagts puts it, in HIL, "[t]he hegemon promotes, by word and deed, new rules of law, both treaty based and customary", chafes at constraints imposed by treaty and presumes that its disregard of customary rules will be accepted as the new norm. ${ }^{17}$

The most acute structural break from the principle of sovereign equality of states is the United Nations Security Council, a body that in the post-9/11 era has at least occasionally become an instrument of HIL. ${ }^{18}$ The Security Council is distinguished from other international organisations both by its exclusive membership and the breadth of its powers.

\section{A Security Council Powers and Authority}

\section{Structural considerations}

Two well-known structural qualities distinguish the Security Council from the General Assembly. First, the Security Council is not a plenary body on which every UN state sits. Instead, it has a rotating non-permanent membership of ten members, selected by their peer states - usually following intense lobbying - to sit on the Council for two years. Even more notably, the final five spots on the Security Council are occupied permanently by five states - the United States, Russia, China, the United Kingdom, and France (the so-called "P5"). ${ }^{19}$

Second, there is a decision-making power imbalance between the permanent and non-permanent members. Pursuant to Article 27 of the UN Charter, each member of the Council - whether

14 Charter of the United Nations (26 June 1945) 59 Stat 1031; TS 993; 3 Bevans 1153, art 18 [UN Charter].

15 Detlev Vagts "Hegemonic International Law" (2001) 95 Am J Int L 843.

16 Jose Alvarez "Hegemonic International Law Revisited" (2003) 97 Am J Int'l L 873, 873

17 Ibid

18 See ibid for a discussion of the Security Council and hegemonic international law (HIL).

19 UN Charter, above n 14, art 23. 
permanent or non-permanent - has one vote and decisions are taken by an affirmative vote of nine members. However, Article 27 generally requires the "concurring votes of the permanent members", at least in relation to non-procedural matters. ${ }^{20}$

\section{Chapter VII and discretionary power}

(a) Nature of powers

The Security Council is also distinguished from other UN organs by the scope of its powers. By virtue of Chapter VII of the UN Charter, the UN Security Council is easily the most potent of the world's international organisations. First, under Article 39, the Council is empowered to decide the existence of "any threat to the peace, breach of the peace, or act of aggression" - all undefined expressions. Second, under Article 40 it may "call upon" states to comply with provisional measures designed to forestall the threat to international peace and security and, under Article 39, may make recommendations on the resolution of the issue. Third, under Article 41, it may impose measures short of force - such as economic or other sanctions. Fourth, under Article 42, where the Security Council considers measures short of force would be inadequate, it may authorise use of military force.

A Security Council resolution issued under Chapter VII - and particularly Articles 41 and 42 is an extremely robust species of international law. In Prosecutor v Dusko Tadic, the International Criminal Tribunal for the Former Yugoslavia (ICTY) noted that Chapter VII decisions are "mandatory vis-à-vis the other Member States, who are under an obligation to cooperate with the Organization."21 Article 25 of the UN Charter specifies that "[t]he Members of the United Nations agree to accept and carry out the decisions of the Security Council in accordance with the present Charter."

(b) Scope of discretion

The Security Council's discretion to impose measures under Chapter VII may not be absolute. It is, however, substantial. In Tadic, ${ }^{22}$ the ICTY recognised that, in deciding whether a threat to peace and security exists under Article 39, the Security Council is not totally unfettered: "it has to remain, at the very least, within the limits of the Purposes and Principles of the Charter."23 However,

20 From this requirement flows the "veto" power of the permanent five members ("P5"). For a discussion (and acceptance) of this practice by the International Court of Justice, see Legal Consequences for States of the Continued Presence of South Africa in Namibia (South West Africa) notwithstanding Security Council Resolution 276 (Advisory Opinion) [1971] ICJ Rep 16, 22 Judgment of the Majority [Namibia Case].

21 Reprinted in Prosecutor v Tadic (1996) 35 ILM 32, 43.

22 Ibid.

23 Ibid, para.29. 
ultimately "[i]t is the Security Council that makes the determination that there exists one of the situations justifying the use of the 'exceptional powers' of Chapter VII."24

The breadth of that discretion should not be underestimated. Since the end of the Cold War, circumstances viewed by the Security Council as constituting a threat to international peace and security have proliferated. Reviewing this pattern, one observer has written: ${ }^{25}$

Since 1992, a wide variety of situations has been classified as a "threat to the peace" by both the

Security Council and the General Assembly. These include the proliferation and development of

weapons of mass destruction (as well as their means of delivery), acts of international terrorism, the use

of mercenaries, emergency situations, and the violent disintegration of states.

Notably, it is also the Security Council that chooses the remedy to the threat it declares. Thus, as the ICTY observed in Tadic, "[o]nce the Security Council determines that a particular situation poses a threat to the peace or that there exists a breach of the peace or an act of aggression, it enjoys a wide margin of discretion in choosing the course of action," 26 albeit one "limited to the measures provided for in Articles 41 and 42."27 Article 41 in particular has a potentially vast ambit. For instance, in analysing Article 41, the ICTY in Tadic held that it includes more than the sample actions included in the provision itself, extending to the creation of an international judicial body; that is, the ad hoc criminal tribunal. ${ }^{28}$

For these reasons, Security Council observers have been unprepared to pin down the precise scope of Council Chapter VII powers. Some authorities have concluded, for instance, that the Council is not limited by existing extra-UN Charter international law in tailoring its Chapter VII resolutions. $^{29}$

(c) Checks and balances in a system of hegemonic international law

If the Security Council is exclusive and unrepresentative, its jurisdiction under the Charter pliable and expanding, and its authority binding, an obvious question is whether any true legal checks curb the Council's activities. There is no actual separation of powers and system of checks

24 Ibid, para 29.

25 Stefan Talmon "The Security Council as World Legislature" (2005) 99 Am J Int'l L 175, 180-1.

Tadic, above n 21 , para 31

27 Ibid, para 32.

28 Ibid, para 34 and following.

29 See discussion in Bruno Simma (ed) The Charter of the United Nations: A Commentary (Oxford University Press, New York, 2002) 711 
and balances in the United Nations structure. ${ }^{30}$ The United Nations Charter seems to anticipate each organ adjudging its own jurisdiction. ${ }^{31}$ Bernhard Graefrath has noted that, in designing the Security Council, the Charter's framers "thought that the system of the veto would suffice as a check and balance device against the plenitude of the Security Council's powers": ${ }^{32}$

They were of the view that the different political interests of several superpowers would prevent decisions of the Security Council from going beyond the Charter, and that this political device would ensure that the UN was not reduced to a tool of one superpower.

Graefrath has warned, however, that this structural check is impaired. It never worked in the Cold War, producing paralysis rather than judicious use of Security Council power. In the immediate post-Cold War period, the internal veto check "lacks teeth because only one superpower remains. The veto therefore does not function as a check and balance mechanism; it has lost its balancing capability." ${ }^{33}$ Put another way, the Security Council is captive to hegemonic international law, at present disproportionately influenced by the United States. ${ }^{34}$

If so, then a key question is whether other UN organs play an oversight role. For instance, the existence of an ICJ judicial review authority has sparked much scholarly controversy. ${ }^{35}$ The matter has not yet been clearly addressed by the ICJ itself, although there have been terse references to the issue from time to time. ${ }^{36}$ The Court may have a collateral judicial review authority; that is, the capacity to query the legality of a Security Council action where that legality is fundamental to

30 Matthias J Herdegen "The 'Constitutionalization' of the UN Security System" (1994) 27 Vand J Transnat'l L 135,150 .

31 See Certain Expenses of the UN [1962] ICJ Rep 151, 168.

32 Bernhard Graefrath "Leave to the Court What Belongs to the Court: The Libyan Case" (1993) 4 Eur J Int'l L $184,203$.

33 Ibid.

34 This is not to say that hegemons always get their way on the Council. Famously, the United States and the United Kingdom faced resistance by other Security Council members (notably, France and Russia) in obtaining a second Council resolution prior to the invasion of Iraq in 2003. However, it is equally notable that post-Iraq invasion resolutions have been accommodating of the US/UK occupation. See discussion in Alvarez, above n 16, 883 .

35 See, for example, Kathleen Renee Cronin-Furman "The International Court of Justice and the United Nations Security Council: Rethinking A Complicated Relationship" (2006) 106 Colum L Rev 435; Jose E Alvarez "Judging the Security Council" (1996) 90 Am J Int'l L 1, 6; Vera Gowlland-Debbas "The Relationship Between the International Court of Justice and the Security Council in the Light of the Lockerbie Case" (1994) 88 Am J Int'l L 643; Graefrath, above n 32.

36 See, for example, Application of the Convention on the Prevention and Punishment of the Crime of Genocide (Bosnia \& Herzegovina v Yugoslavia (Serbia \& Montenegro)) [1993] ICJ Rep 407, 440, para 99 Lauterpacht; Questions of Interpretation and Application of 1971 Montreal Convention Arising from Aerial Incident at Lockerbie (Libyan Arab Jamahiriya v United States) [1998] ICJ Rep 9, 76 President Schwebel. 
deciding either an advisory question put to the Court, or a dispute between states in a contested case. ${ }^{37}$ However, even then, a determination by the Court that a given action by the Security Council was ultra vires would not be binding on the Security Council itself. ${ }^{38}$ Put another way, the ICJ - the UN's key judicial organ - has at best rudimentary review jurisdiction over the Security Council.

Nor is it possible to conceptualise the relationship between the General Assembly and the Security Council as even roughly analogous to that of legislature and executive in domestic political systems. First, the General Assembly has no autonomous law-making powers, being competent only to recommend courses of action. ${ }^{39}$ Further, the General Assembly's consideration of matters relating to peace and security can be supplanted by the Security Council, when the latter chooses to seize itself of the question. ${ }^{40}$ The UN system differs, in other words, from the standard democratic model in which a legislative branch exercises some review or oversight (and often primacy) over executive action.

\section{THE UN SECURITY COUNCIL'S LEGISLATIVE PHASE AND DEMOCRACIES}

As the discussion up to this point suggests, jurists have spilled substantial ink discussing the muscular Security Council. Lurking in the midst of the discussion on "hegemonic international law", however, is another related issue, one less concerned with hierarchy and separation of powers within the international order and more preoccupied with the implications of HIL for domestic legal systems. Specifically, what impact does HIL via the Security Council have for the model of democratic accountability set out in Part I of this article?

The section that follows discusses recent Security Council practice that some commentators have labelled its "legislative" phase. It proposes that Security Council resolutions of this sort sit uncomfortably with classic democratic separation of powers doctrines. For countries like Canada, hegemonic international law expressed through the vehicle of the Security Council risks creating an ascendant executive branch, one serving as a mere proxy for international hegemons.

37 See Namibia Case, above n 20, 45.

38 Ibid. Note Article 59 of the Statute of the ICJ: "The decision of the Court has no binding force except between the parties and in respect of that particular case." The Security Council would not be a party.

39 UN Charter, above n 14, art 10.

40 Ibid, art 12. Note, however, that the ICJ has given a narrow reading to the Security Council's power to usurp consideration of peace and security matters by the General Assembly. Legal Consequences of the Construction of a Wall in the Occupied Palestinian Territory (9 July 2004) ICJ General List No 131; 43 ILM 1009, para 27. 


\section{A The Security Council's Legislative Phase}

As noted above, there is nothing new about the breadth of Security Council Chapter VII powers. They have existed on paper since the formation of the United Nations in the immediate aftermath of World War II. Those powers were rarely exercised, however, in the Cold War that followed. Instead, the period of 1946 to 1990 was the era of P5 vetoes, not cooperation. Famously, the immediate post-Cold War era was followed by more concerted Chapter VII activity by the Council, most notably in the Gulf War of 1990-1991. Although frayed by the late 1990s, multilateral consensus on the Council was restored - albeit unevenly - by terrorism-related issues and the events of 9/11. Notably, in dealing with terrorism matters, the Council has chosen to exercise its Chapter VII powers in an unprecedented manner.

\section{Resolution 1267}

Thus, the Security Council issued Resolution 1267 in October 1999. ${ }^{41}$ Targeting the Taliban, then the de facto government in Afghanistan, the resolution creates a sub-committee of the Council ("1267 Committee") charged with listing individuals affiliated with this group. It then calls on governments to bar financial transactions by their nationals or those within their territories with the listed persons. Resolution 1333 extended these provisions to Osama Bin Laden and his associates (including Al Qaeda) in 2000. ${ }^{42}$ The basic architecture of these resolutions remains intact, as modified and enhanced by several additional resolutions. ${ }^{43}$ Several hundred persons and entities are now listed. ${ }^{44}$

The 1267 process represents an unusually detailed and intrusive sanctioning regime, one that implicates the Security Council in the almost quasi-judicial function of identifying individual suspected terrorists and terrorist entities. The current 1267 Committee rules simply provide that persons will be placed on the terrorist list on the basis of relevant information provided by member states. The latter are to provide "a narrative description of the information that forms the basis or justification for taking action." 45 The Committee considers requests "expeditiously" 46 and decides

41 UNSC Resolution 1267 (15 October 1999) (54) S/RES/1267.

42 UNSC Resolution 1333 (19 December 2000) (55) S/RES/1333.

43 S/RES/1364 (2001); S/RES/1388(2002); S/RES/1390 (2002); S/RES/1452(2002); S/RES/1455 (2003); S/RES/1456 (2003); S/RES/1526 (2004); S/RES/1617 (2005). As this article was prepared for publication, the Security Council issues two new resolutions - S/RES/1730 (2006) and S/RES/1735 (2006) that change somewhat the listing and delisting processes discussed in this section.

44 See United Nations The New Consolidated List of Individuals and Entities Belonging to or Associated with the Taliban and Al-Qaida Organisation as Established and Maintained by the 1267 Committee www.un.org (accessed 20 December 2006).

451267 Committee Guidelines of the Committee for the Conduct of its Work (adopted on 7 November 2002, as amended on 10 April 2003 and revised on 21 December 2005) www.un.org (accessed 20 December 2006)

46 Ibid, 4. 
whether to list the individual on a consensus basis. ${ }^{47}$ There is, however, no adjudication of guilt and no opportunity for the person so designated to make representations. Indeed, the Committee generally meets in closed sessions. ${ }^{48}$

Blacklisting by the 1267 Committee does not compel prosecution. Listed persons are not deemed criminals, in other words, nor does the 1267 process oblige their incarceration. Arguably, due process protections associated with criminal law - not least fair trial rights in the International Covenant on Civil or Political Rights - should therefore be inapplicable to the 1267 process. Nevertheless, as the Liban Hussein case discussed below suggests, listing may undergird a criminal prosecution of a listed person under at least the laws of Canada. In these circumstances, listing risks amounting to a virtual "bills of attainder"; that is, declaring by writ the guilt of an individual, without benefit of a trial. For exactly this reason, the due process implications of listing are significant, and indeed, the 1267 Committee process as a whole may be extremely vulnerable to abuse by states with ulterior motives for terrorist listing. ${ }^{49}$

Subsequently, if a wrongfully listed person wishes to be removed from the UN list, they are at the mercy of a very political UN process. First, they must petition their government of residence or citizenship (the "petitioned" state) to intervene, providing justification for the de-listing request. That petitioned state may then approach the governments that originally proposed the listing ("designating" states), holding bilateral consultations and collecting additional information. The rules specify that the petitioned government "should seek to persuade the designating government(s) to submit jointly or separately a request for de-listing to the Committee." Alternatively, the petitioned government may act unilaterally, with the de-listing request circulated to Committee members and deemed approved where no objections are voiced. ${ }^{50}$ As this latter process suggests, the 1267 Committee renders a de-listing decision on a consensus basis. If no consensus exists on the Committee, the matter is returned to the full-fledged Security Council. ${ }^{51}$ Presumably, at the Security Council, to be de-listed, at least 9 members would have to agree and every single permanent member would have to decline a veto. The consensus approach to 1267 Committee decision-making places each member of the Security Council in a spoiler position. ${ }^{52}$

47 Ibid, 2 ("The Committee shall make decisions by consensus of its members").

48 Ibid, 2.

49 See discussion in Eric Rosand "The Security Council's Efforts To Monitor The Implementation Of Al Qaeda/Taliban Sanctions" (2004) 98 Am J Int'l L 745, 752; International Helsinki Federation for Human Rights Anti-terrorism Measures, Security and Human Rights: Developments in Europe, Central Asia and North America in the Aftermath of September 11 www.ihf-hr.org (accessed 20 December 2006) 130.

51 Ibid, 6 .

52 For a discussion of this issue, involving a case from Sweden, see Rosand, above n 49, 749-750. 
Perhaps even more troubling, nothing in this 1267 Committee process appears to grapple with a situation in which a petitioned state is also the designating country, and that designating country is motivated by malice towards some political opponent who they wished listed as a terrorist. As the International Helsinki Federation for Human Rights notes, "there appears to be no remedy for those included on the list at the behest of their own governments." ${ }^{53}$ In these circumstances, it is difficult to see how a de-listing would be accomplished.

For all these reasons, this process has been roundly condemned, not least by the UN SecretaryGeneral's recent High-Level Panel on UN reform. ${ }^{54}$ European states have also expressed strong concerns. $^{55}$

\section{Resolutions 1373 and 1540}

In the immediate aftermath of the terrorist attacks on New York and Washington, the Council issued Resolution 1373, acting pursuant to its Chapter VII powers. Among other things, the Resolution requires that "terrorist acts are established as serious criminal offences in domestic laws and regulations and that the punishment duly reflects the seriousness of such terrorist acts". This measure - reaching deep inside domestic legal systems - has been described as a form of Security Council "legislation." ${ }^{56}$ It differs markedly from prior Security Council practice. Canvassing past Security Council resolutions, Eric Rosand notes three important distinctions between resolution 1373 (and resolution 1540, described below) and their precursors: First, Security Council resolutions in the past have been temporally and geographically restricted, often directed at a particular civil or regional conflict. Resolution 1373, by comparison, is global and of indefinite duration. Second, prior resolutions were designed to compel compliance with Council dictates by a target state, not to create generic obligations for the international community. Third, prior to resolution 1373, the Council had never promulgated a measure setting out "a broad set of rules or norms", let alone in "areas of law where it is usually left to States to agree among themselves, where

53 International Helsinki Federation for Human Rights, above n 49. This concern may now be partially alleviated by developments that arose while this article was being prepared for publication; namely, the introduction of a standing UN "focal point" to receive delisting requests as an alternative to proceeding by way of a petitioned state."

54 United Nations Secretary General's High-Level Panel on Threats, Challenges and Change "A More Secure World: Our Shared Responsibility" (2 December 2004) A/59/565, para 152.

55 See, for example, Richard Ryan, permanent representative of Ireland to the United Nations "Statement on Behalf of European Union" (12 January 2004) S/PV.4892, 23.

56 See Alvarez, above n 16, 874; Paul C Szasz "The Security Council Starts Legislating" (2002) 96 Am J Int'l L 901. 
other international bodies have been working for a number of years, and which are already governed by extensive multilateral treaty regimes." 57

Summing up resolution 1373's sui generis quality, Jose Alvarez describes the measure as a "legally binding regulation, backed by the possibility of real enforcement action, imposed on all states by a global international organ engaged in a continuous legislative enterprise by virtue of delegated power and subject to no geographic or temporal limitation." ${ }^{15} \mathrm{He}$ also identifies it as a manifestation of hegemonic international law: a selective extraction of provisions from the International Convention for the Suppression of the Financing of Terrorism ${ }^{59}$ that ignores some of that treaty's nuance and countenances no negotiation of detail; the latter being the sine que non of conventional international law-making via treaty.

Whether the Security Council will persist in performing this more intrusive, legislative function remains unclear. It is notable, however, that resolution 1373 is no longer unique in obliging states to amend domestic laws, ${ }^{60}$ a development provoking substantial commentary. ${ }^{61}$

\section{B Canadian Implementation of Security Council Resolutions}

This discussion begs the question: how do states implement "legislative" Security Council resolutions? Implementation is obviously governed by each state's domestic legal apparatuses. In Canada, foreign affairs are a federal responsibility, exercised in large measure by the federal executive as part of its royal prerogative. ${ }^{62}$ The prerogative's precise content is often uncertain. Nevertheless, deploying the Canadian Forces overseas is a classic royal prerogative power, most

57 Eric Rosand "The Security Council as 'Global Legislator': Ultra Vires or Ultra Innovative?" (2005) 28 Fordham Int'l LJ 542, 567.

58 Alvarez, above n 16, 874.

59 UNGA Resolution 109 (25 May 2000) A/54/49.

60 See, for example, UNSC Resolution 1540 (28 April 2004) S/RES/1540 (deciding that "all States, in accordance with their national procedures, ... adopt and enforce appropriate effective laws which prohibit any non-State actor to manufacture, acquire, possess, develop, transport, transfer or use" weapons of mass destruction).

61 The scope of resolution 1540 did not escape comment during the drafting process. Discussing the negotiating process surrounding Resolution 1540 in 2004, the Security Council's then-president described the Security Council as acting to "legislate for the rest of the United Nations' membership", a function that the Council would increasingly fulfill. The president acknowledged that questions of legitimacy would flow from this practice, generating new concerns about a Security Council unrepresentative of the world community. Security Council President "Press Conference by Security Council President" (2 April 2004) Press Release: www.un.org (accessed 19 December 2006).

62 See Black $v$ Canada 54 OR (3d) 215 (CA) for a brief discussion of prerogative powers in the context of foreign affairs. 
likely exercisable without recourse to Parliament. ${ }^{63}$ Thus, in Canadian law, compliance with a Chapter VII resolution authorising the use of force would not trigger legal processes implicating Parliament.

On the other hand, a Security Council resolution requiring measures short of force could oblige actions outside the purview of the federal executive's prerogative. The most commonplace resolution - one calling for trade and investment sanctions - implicates a broad swath of private sector actors. There is no serious possibility that the executive could claim some residual prerogative jurisdiction to regulate these persons. ${ }^{64}$

Thus, largely to expedite compliance with the classic sanctions-oriented Chapter VII resolution, the Canadian Parliament enacted the United Nations Act. ${ }^{65}$ This short statute empowers the federal cabinet to make orders and regulations that appear to it "to be necessary or expedient" as means to implement a measure called for by the UN Security Council under Article 41 of the United Nations Charter. Put another way, it delegates authority to the federal executive to legislate via regulations, a commonplace and entirely constitutional practice in Canadian law. Under the Act itself, a violation of these regulations is a crime, attracting a substantial penalty of up to ten years imprisonment. ${ }^{66}$

With one exception discussed below, the existing United Nations Act regulations all involve classic sanctions measures, often relating to arms sales to geographically-defined, sanctioned regimes, groups or persons. ${ }^{67}$ These provisions bar persons in Canada and Canadians outside Canada from engaging in the prohibited transactions with the sanctioned entity.

More notably, however, the Security Council's post-9/11 anti-terrorism measures present a challenge to Canada's typical resolution compliance regime. First, they have prompted the government to stretch the limits of the United Nations Act in a potentially problematic manner.

63 See Michel Rossignol, Library of Parliament Parliament, the National Defence Act and the Decision to Participate www.parl.gc.ca (accessed 19 December 2006) for a discussion of the uncertain role of the Canadian Parliament in international military deployments.

64 Reference re Anti- Inflation Act [1976] 2 SCR 373, 433 ("There is no principle in this country, as there is not in Great Britain, that the Crown may legislate by proclamation or order in council to bind citizens where it so acts without the support of a statute of the Legislature").

66 United Nations Act, s 3.

67 United Nations Iraq Regulations (SOR/90-531 and SOR/2004-221); United Nations Liberia Regulations (SOR/2001-261); United Nations Rwanda Regulations (SOR/94-582); United Nations Sierra Leone Regulations (SOR/98-400); United Nations Sudan Regulations (SOR/2004-197); United Nations Democratic Republic of the Congo Regulations (SOR/2004-222); and United Nations Côte d'Ivoire Regulations (SOR/2005-127). 
Second, they have compelled the government to ask Parliament for new statute law, urging that this legislation must be enacted (and swiftly) to comply with Canada's international obligations.

\section{Resolutions 1267, 1373 and the United Nations Act}

Soon after Security Council Resolution 1267 was issued in 1999, the Canadian federal executive issued the United Nations Afghanistan Regulations, ${ }^{68}$ made pursuant to the United Nations Act. This instrument was amended in early 2001 to reflect the inclusion of Al Qaeda by resolution 1333. ${ }^{69}$ The regulations incorporate - obliquely - the 1267 Committee listing process into their fabric by defining the Taliban and Al Qaeda as "according to" the Committee. They bar dealing in the property of these entities, or providing financial services to them.

While the Afghanistan Regulations remain on the books, the government responded to the 9/11 events separately. Thus, in October 2001, it issued the United Nations Suppression of Terrorism Regulations, ${ }^{70}$ again made pursuant to the United Nations Act. In this case, the regulations responded to Security Council Resolution 1373, and particularly its terrorist financing provisions.

These Suppression of Terrorism Regulations easily constitute the most sweeping use of the United Nations Act to date. First, the exact reach of these provisions is mutable, depending on the periodic "listing" of individuals and entities as banned persons. In the current version of the instrument, a person may be "listed" under the regulations on two bases. The government may unilaterally list someone where there are reasonable grounds to believe that person has carried out, participated in or facilitated a terrorist activity, or has sufficient ties to someone who has (hereafter "unilateral listing"). A person is also incorporated in the Canadian list because they have been identified as a Taliban or Al Qaeda member by the 1267 Committee (hereafter "UN listing").

Second, the conduct criminalised by the regulations reaches well beyond prior precedents, regulating a broad swath of economic actors and extending beyond the narrow geographic focus of typical UN resolution implementation provisions. Thus, the Canadian regulations criminalise a number of different sorts of transactions with persons listed in either of the two ways.

The shortcomings of the Suppression of Terrorism Regulations became apparent soon after their introduction. In November 2001, Liban Hussein, a resident of Ottawa, Canada, was indicted in Massachusetts for the operation of an unlicensed money transfer business, said to have moved US\$3

68 United Nations Afghanistan Regulations (SOR/99-444).

69 Amended United Nations Afghanistan Regulations (SOR/2001-86). It was amended again in 2004 by SOR/2004-160 to reflect the nuance in the Afghan sanctions regime introduced by Security Council Resolution 1390 (2002) and 1526 (2004).

70 United Nations Suppression of Terrorism Regulations (SOR/2001-360). 
million to the United Arab Emirates during the first nine months of 2001. ${ }^{71}$ The charges stemmed from the unlicensed nature of the money transfer business undertaken by Mr Hussein's United States-based firm, but were part of larger efforts of United States officials to shut down the operations of suspected terrorist financiers. Mr Hussein was listed soon after the United States charges were laid by Canada under the Suppression of Terrorism Regulations, ${ }^{72}$ pursuant to the unilateral listing power under that instrument. Mr Hussein's assets were immediately frozen, reportedly ruining him. ${ }^{73}$

The United States then sought Hussein's extradition from Canada to face trial in the United States. Canada had no equivalent crime to the licensing misdemeanor with which Hussein was charged in the United States. Canadian Federal Justice Department officials, however, treated the Suppression of Terrorism Regulations listing as meeting the standard dual criminality requirement in extradition law. In essence, Mr Hussein had committed the crime of having financial dealings with a listed person - namely, himself and his companies - thus justifying his removal to the United States to serve trial for unlicensed money transfers. ${ }^{74}$

That dubious extradition effort collapsed in June 2002 when the Canadian Government concluded that "[b]ased on a full and thorough investigation of the information collected in relation to the extradition proceedings, the Government of Canada has concluded that there are no reasonable grounds to believe Mr Hussein is connected to any terrorist activities."75 The Government then removed him from its list under the Suppression of Terrorism Regulations, and ultimately paid an undisclosed amount in compensation for financial and emotional hardship. ${ }^{76}$

However, by November 2001, the 1267 Committee had also listed Mr Hussein. ${ }^{77} \mathrm{He}$ was, therefore, still subject to international censure. In June 2002, Canada promised to seek his de-listing at the United Nations and in fact, Mr Hussein was deleted from the 1267 Committee list in July

71 See discussion in Michael Chertoff, Assistant Attorney General, Criminal Division (29 January 2002) "The Financial War on Terrorism and the Administration's Implementation of the Anti-Money Laundering Provisions of the USA Patriot Act" Press Release www.yale.edu (accessed 21 December 2006)

72 Suppression of Terrorism Regulations (SOR/2001-491).

73 See Jake Rupert "Government pays off victim of terror smear: Ottawa man was arrested, his business ruined" (2 October 2003) The Ottawa Citizen A1.

74 See discussion in E Alexandra Dosman "For the Record: Designating 'Listed Entities' for the Purposes of Terrorist Financing Offences at Canadian Law" (2004) 62 UT Fac L Rev 1, 17.

75 Justice Canada "Canada Halts Extradition, Liban Hussein De-Listed" (3 June 2002) Press Release www.justice.gc.ca. See SOR/2002-210 and SOR/2002-211.

76 Rupert, above n 73.

77 UN Press Release SC/7206 (9 November 2001). 
2002. ${ }^{78}$ The 1267 Committee subsequently introduced the formal process for de-listing described above. $^{79}$

The Liban Hussein case is a strongly cautionary tale. Certainly, the outcome in that matter was satisfactory. However, the delisting of Mr Hussein on the 1267 Committee depended in large measure on the cooperation of the United States. ${ }^{80}$ Absent that agreement, Mr Hussein would not have been de-listed.

\section{Resolution 1373 and the Anti-terrorism Act}

The Canadian government responded to the post-9/11 Security Council resolutions with more than regulations under the United Nations Act. In the immediate aftermath of 9/11, the government introduced Bill C-36 in Parliament. A massive omnibus bill, C-36 was enacted at dizzying speed in just over two months as Canada's Anti-terrorism Act. ${ }^{81}$ The law is sweeping, creating a new definition of terrorist activity in Canada's Criminal Code and barring multiple terrorism-related financial activities. More than this, the law includes significant new government secrecy laws.

In its reporting to the UN Security Council on anti-terrorism measures, Canada characterises Bill C-36 as responsive to Resolution $1373 .{ }^{82}$ As described by the then-deputy prime minister to a parliamentary committee in 2002, "[t]he Anti-terrorism Act is an unprecedented piece of legislation and brings Canada into full compliance with United Nations Security Council Resolution 1373."83 Likewise, Canada's then-justice minister told a parliamentary committee in 2005 that specific offences in Bill C-36 were enacted to comply with the Security Council's dictates. ${ }^{84}$

This author is aware of no other Canadian legislative provision enacted specifically to comply with Security Council instructions.

78 UN Press Release SC/7447 (10 July 2001).

79 UN Press Release AFG/203-SC/7487 (16 August 2002).

80 Colum Lynch "US Seeks to Take 6 Names Off U.N. Sanctions List; Administration Was Criticized for Offering Little Proof That Individuals, Groups Aided Al Qaeda" (22 August 2003) Washington Post A13.

81 Anti Terrorism Act RSC 2001, c 41

82 See, for example, Report of the Government of Canada to the Counter-Terrorism Committee of the United Nations Security Council on Measures Taken to Implement Resolution 1373 www.dfait-maeci.gc.ca (accessed 20 December 2006).

83 John Manley (Deputy Prime Minister, Lib) "Evidence to 37th Parl, 1st Sess, Sub-Committee on National Security of the Standing Committee of Justice and Human Rights" (April 10, 2002) http://cmte.parl.gc.ca (accessed 20 December 2006).

84 Irwin Cotler (Minister of Justice and Attorney General of Canada) "Evidence to 38th Parl, 1st Sess, Proceedings of the Special Senate Committee on the Anti-terrorism Act Issue 2 (February 212005 ) www.parl.gc.ca (accessed 20 December 2006) 


\section{Resolutions 1267 and 1373 and Hegemonic Federalism}

\section{Executive ascendancy, hegemonic federalism and Parliament}

As this discussion suggests, the Security Council's post-9/11 activity signals important "constitutional" developments in the world legal system. Put most bluntly, an exclusive, unrepresentative international political entity, subject to no review or oversight by any other international political or judicial body, now dictates the content (or at least directs the creation) of domestic laws. In so doing, Security Council action skews the balance between executive and legislative branches of government.

This is true even for the world's hegemon. In the United States, a key question is whether legislative authority asserted by an international body impairs the domestic United States constitutional doctrine of non-delegation of congressional legislative powers. ${ }^{85}$ Whatever the precise answer to this legal question, it is clear also that the relationship between the President and Congress is affected by Security Council action. The United States participates on the Council, but the executive, not Congress, exercises decision-making at that level. In circumstances where the United States exercises hegemonic authority - and can disproportionately influence Council action executive primacy produces what might be termed a "reverse" delegation of power. ${ }^{86}$ That is, by exercising its influence over Council behaviour, the United States executive may "launder" an executive power-grab, converting action dubious under domestic United States law into a multilateral, international matter arguably falling within the President's purview. ${ }^{87}$ International instruments may also accelerate a closer, detailed presidential control over administrative decisionmaking within the executive branch itself, bringing the otherwise sometimes inchoate actions of a sprawling bureaucracy into alignment with presidential priorities. ${ }^{88}$ Presidentially-directed administrative action may be harmonised around anti-terrorism objectives, ${ }^{89}$ including those enunciated by the Security Council.

85 See discussion in Edward T Swaine "The Constitutionality of International Delegations" (2004) 104 Colum L Rev 1492.

See ibid, 1609 for a discussion of "reverse" delegations, albeit in a different context.

87 This tendency has become acute in the area of "war powers", an area of frequent contention pitting Congress's power to declare war and the President's prerogatives as "commander in chief." See Louis Fisher Presidential War Power (2 ed, University Press of Kansas, Lawrence (Kansas), 2004).

88 For a discussion of expanding presidential control over administration, even pre-9/11, see Elena Kagan "Presidential Administration" (2001) 114 Harv L Rev 2245.

89 See, for example, William J Stuntz "Terrorism, Federalism, and Police Misconduct" (2002) 25 Harv JL \& Pub Pol'y 665, 675 (suggesting that the prominence of anti-terrorism may prompt closer oversight of law enforcement actions in the area by the political executive). 
For states like Canada - only occasionally a member of the Council and unable to exercise a P5 veto - there is rarely any "reverse" delegation: the Canadian executive has generally not participated in the framing of the resolution. Nevertheless, that executive is empowered in specific ways relative to the legislature by the Security Council resolution.

First, where new statutory law is required to comply with Security Council resolutions, the legislature is told by the government that it has little or no discretion in deciding whether to act: the law project is necessitated by Canada's international obligations. Careful democratic deliberation by elected parliamentarians is likely chilled. The Anti-terrorism Act in Canada provides a case in point.

Second, where existing Canadian legislation delegates the power to comply with Security Council resolutions to the executive, aggressive Security Council action amplifies executive powers. For example, the crimes created by regulation under the Canadian Suppression of Terrorism Regulations are significant offences, in many ways repetitive of what was later enacted by the Antiterrorism Act. Yet, unlike the latter law, the government relied on the United Nations Act's generic delegation of authority to create an unusually detailed menu of new crimes never vetted by Parliament. Indeed, there is no reason to believe Parliament ever conceived of such sweeping use of the Act, given the usually more modest economic sanctions regimes typical of the UN Security Council.

At present, therefore, aggressive Security Council resolutions coupled with the blank implementation writ offered by the United Nations Act opens up vast new terrain for federal executive law-making. However, this federal law-making is responsive to the Security Council's dictates. Executive law-making, in other words, serves as a conduit for converting Security Council legislation into domestic law.

The result is an interface between domestic and international systems best described as "hegemonic federalism": a system in which law-projects are mandated by a superior, international order of government, and then implemented at the national level directly by executive fiat (or, as in C-36, by a compliant legislature).

\section{Executive ascendancy, hegemonic federalism and the judiciary}

These observations provoke a final line of inquiry: what impact does the Security Council's legislative action have on the relationship between the judiciary and the other branches of government? As a matter of Canadian law and practice, this question cannot be answered definitively, rendering this last section speculative.

Certainly, the provisions of the Anti-terrorism Act are as susceptible to judicial review on constitutional grounds as any other Act of Parliament. Likewise, regulations introduced under the United Nations Act would be reviewable on constitutional grounds. For instance, constitutional scrutiny of the Suppression of Terrorism Act is inevitable if the government were ever to bring a prosecution under those regulations. It could be, in other words, that a court would be asked 
whether a UN listing process, incorporated into Canadian law, complied with Canadian constitutional law.

In the past, Canadian courts have not considered relevant, in deciding a law's constitutionality, the fact that it implements an international obligation. ${ }^{90}$ Should this propensity prevail, the judiciary would constitute a check on "hegemonic federalism", at the expense of potentially placing Canada out of compliance with its formal international obligations under the UN Charter.

\section{CONCLUSION}

By design, the United Nations system accommodates both democratic and non-democratic governments. In this manner, it reflects a traditional international legal indifference for the type of government existing within states. States are sovereign equals, whether democracies, monarchies, one-party governments or outright dictatorships. The cost of sovereign equality - and the related concept of state consent in the promulgation of international law - is the terrible things sometimes done under the banner of sovereignty, most notably by repressive regimes. But sovereignty also insulates democracies, leaving these states to function largely unimpaired in an environment where, until recently, most states were not democratic.

Because of its potent Chapter VII powers, the Security Council has always constituted an important caveat to the sovereign equality that otherwise runs through the UN system. The Council sits at an important junction between the world and domestic constitutional orders: exceptionally among international institutions, it is an entirely unrepresentative body able to deploy a very broad discretion to mandate state behaviour. The implications of this Council exceptionalism for democracies have been obscured, until recently, by that body's veritable paralysis.

Squabbles over Iraq aside, the Council now operates with greater efficiency, and has moved into an unprecedented legislative phase, one that imposes law-making obligations on states. In states like Canada, this new trend acerbates a common tendency in modern democracies: the relative importance of executive government. A combination of sweeping delegations of Security Council resolution implementation responsibilities to the executive and the natural propensity of the legislative branch to comply, at the urging of the executive, with Canada's international obligations amplifies executive ascendancy. The new executive powers are not, however, exercised autonomously, but rather in response to the instructions of the Security Council - itself perhaps responding to the interests of its hegemon(s). The result is a grafting of a new form of hegemonic federalism onto the Canadian state - one in which the Security Council asserts plenary law-project authority over the federal executive, which in turn responds with direct implementation of the international resolution or strongly encourages (and in majority parliaments likely ensures) compliance by parliament.

90 See, for example, Labour Conventions Case (Attorney-General for Canada v Attorney-General for Ontario) [1937] AC 326 (PC). 
Whether domestic judicial review will limit this system of "hegemonic federalism" and the emasculation of legislative authority is uncertain. What is clear, however, is that the Security Council's new legislative phase raises more than simply questions of sovereignty. It also creates new dilemmas for democratic accountability. Put simply, can a system of democratic accountability persist where those voted into office to represent the interests of their constituents subsequently march to the drumbeat of international hegemonic law? 
